\title{
Xylanase Production by Streptomyces viridosporus T7A in Submerged and Solid-State Fermentation Using Agro- Industrial Residues
}

\author{
Luiz Romulo Alberton ${ }^{1,2}$, Luciana Porto de Souza Vandenberghe ${ }^{2}$, Ricardo Assmann, \\ Ricardo Cancio Fendrich ${ }^{2}$, José Rodriguéz-León ${ }^{2}$ and Carlos Ricardo Soccol ${ }^{2 *}$ \\ ${ }^{1}$ Universidade Paranaense; Campus Umuarama; Umuarama - PR - Brasil; ${ }^{2}$ Divisão de Engenharia de \\ Bioprocessos e Biotecnologia; Departamento de Engenharia; Universidade Federal do Paraná; Curitiba - PR - \\ Brasil
}

\begin{abstract}
The study of xylanase production was conducted by Streptomyces viridosporus T7A in submerged (SmF) and solidstate fermentation (SSF), using agro-industrial residues and sub-products. Napier grass, sugarcane bagasse and soybean bran were used as carbon source, substrate/support, and nitrogen source, respectively. In SmF, Napier grass $(1 \% \mathrm{v} / \mathrm{w})$ supplemented with soybean bran, hydroxyethylcellulose and B complex vitamins were used. Soybean bran $(1.5 \% w / v), B$ complex vitamins $(0.1 \%)$, and hydroxyethilcellulose $(0.15 \%)$ led to an increase in xylanase production $(23.41 \mathrm{U} / \mathrm{mL})$. In $\mathrm{SSF}$, the effects of the following parameters were studied: substrate composition (sugarcane bagasse, Napier grass and soybean bran), initial moisture, and inoculum rate. In SSF, the highest xylanase activity (423.9 U/g) was reached with: $70 \%$ sugarcane bagasse, 20\% Napier grass and 10\% soybean meal, $90 \%$ of moisture, and $10^{7} \mathrm{~g}$ substrate.
\end{abstract}

Key words: Streptomyces; xylanase, submerged fermentation, solid-state agro-industrial fermentation, residues

\section{INTRODUCTION}

Hemicelluloses are polysaccharides of low molecular weight associated with cellulose and lignin in the cells of plants. Xylanes are the greatest hemicellulosic components of wood and grass, constituting around $25 \%$ of their total biomass (Georis et al., 2000).

During the last decade, researchers have been largely interested in the potential biotechnological uses of xylanases. Products of xylan hydrolysis (xylose and oligossacharides) may be used both in the food industry, as fat substitutes and antifreeze additives, and in the pharmaceutical industry. As it hydrolyzes, xylan may also be converted into liquid fuel, proteins isolated from cells, solvents and low calorie artificial sweeteners. Complete xylan hydrolysis requires the action of many enzymes, such as endo- $1 \beta$-xylanases, which are crucial for depolymerization (Georis et al., 2000). Xylanases have a potential application in increasing digestibility of lignocellulosic material

\footnotetext{
* Author for correspondence: soccol@ufpr.br
} 
for animals (Georis et al., 2000; Alberton et al.,2006). Animal feed industry is an important agribusiness sector, with an annual production of 600 million tons of feed, and more than US\$ 50 billion income.

At this moment the xylanase production was achieved by different technique, as submerged fermentation $(\mathrm{SmF})$ and solid-state fermentation (SSF), using agro-industrial residues (Goyal et al., 2008; Kronauer et al., 2007; Rawashdeh, 2005). Although, substrate derivatives and the final product of the enzymes may frequently work as key factors and influence positively xylanase induction, they may also act as inhibitors in high concentrations (Kulkarni et al., 1999). Catabolic repression caused by glucose is a commonly observed phenomenon in xylanase biosynthesis. Enzyme synthesis was repressed when easily metabolizable carbon sources were present in the medium, suggesting that enzyme synthesis is controlled by a transitory regulatory status and catabolic repression (Kulkarni et al., 1999). Concerning metallic ions, xylanases of Streptomyces sp AMT-3 were strongly inhibited by the addition of copper, manganese, and iron ions (Nascimento, 2002). In a lignocellulosic substrate, Streptomyces viridosporus T7A is capable of producing enzymes of agro-industrial interest such as lignin peroxidase, xylanase, esterase, and cellulase (Ramachandra et al., 1987).

Solid-state fermentation (SSF) presents some advantages over submerged fermentation concerning the readiness of recuperation of bioproduct, besides the use of natural substrates such as nutritional support. Several agricultural or agro-industrial residues, cellulosic or amilaceous, have been used in solid-state fermentation such as sugarcane bagasse, cassava bagasse, rice and wheat bran, coffee husks, and others (Soccol and Vandenberghe, 2003). Low moisture content in SSF provides lower volume of reactor per mass of subtract than in $\mathrm{SmF}$ and it also simplifies the product recovery.

Environmental aspects such as temperature, $\mathrm{pH}$, water activity, oxygen levels, and concentration of nutrients and products significantly affect microbial growth and formation of products. In submerged cultures, environmental control is relatively simple due to homogeneity of the cell microbial suspension, nutrient solution, and the products at the liquid stage. On the other hand, aeration is easier than in submerged processes because of the high diffusion rate of the aqueous film on the solid particle and the large contact surface among the gaseous, solid, and mycelia states (Machado, 2000). In SSF, aeration is performed by the insertion of sterile compressed air through the bed fermentation system (forced aeration) or simply by diffusion in static conditions (Lonsane et al., 1985, Soccol and Vandenberghe, 2003).

Biomass determination is one of the most critical points of SSF. The techniques easily used for SmF are impractical in SSF. In SSF, the biomass is associated to substrate-support in such a way that physical separation for its quantification is not easy. The indirect determination techniques are based on correlation through culture of metabolites from biomass (glycosamine, proteins, ergostrerol, DNA, ATP, etc.) (L.I., 1995, Soccol et al., 1995 Soccol and Vandenberghe, 2003, Prado et al., 2004).

Then, it is understood that the problem to be solved in order to obtain better understanding of these systems concerns the characterization of the kinetics of biomass production as well as the development of mathematic models necessary to optimize these types of processes (Raimbault and Alazard, 1980; Rodriguez et al., 1997). Both $\mathrm{O}_{2}$ consumption and $\mathrm{CO}_{2}$ production is the result of respiration and the metabolic activities are associated with growth (Prado et al., 2004).

In laboratory scale, the most used bioreactors in SSF cultures are erlenmeyer flask, tray-type bioreactors (aeration by diffusion), glass columns immersed in temperature-controlled baths, and horizontal drums (forced aeration). They can be used for development of different bioprocesses including the production of enzymes, organic acids, antibiotics, hormones.

This work had the purpose to comparatively produce xylanase in SmF and SSF by $S$. viridosporus T7A using sugarcane bagasse, wheat bran and Napier grass. SSF was carried out in different models of bioreactors: erlenmeyer flasks, tray-type bioreactor and horizontal drum. Some physical and chemical conditions of the process were studied with respect to both techniques.

\section{MATERIAL AND METHODS}

\section{Microorganism}

The strain used in this study was acquired from the American Type Culture Collection - Streptomyces 
viridosporus T7A (ATCC 39115). It was kept in YM agar (yeast extract malt agar) at $4^{0} \mathrm{C}$.

\section{Spores suspension}

Cells were suspended in $50 \mathrm{ml}$ of sterile water in an erlenmeyer flask with two drops of Tween 80, and sterile glass beads. With the aid of a magnetic stirrer, flasks were shaken for $15 \mathrm{~min}$ for spores to be adequately suspended. This solution was kept in refrigeration at $4^{\circ} \mathrm{C}$ in erlenmeyer flasks for up to six days.

\section{Inoculum production}

Spore suspension was activated in erlenmeyer flasks at $37^{\circ} \mathrm{C}$ in a shaking incubator at $150 \mathrm{rpm}$, using a nutritive solution containing: $0.6 \%$ yeast extract and salt solutions (g/L): $\mathrm{NaHPO}_{4}(5.3)$; $\mathrm{K}_{2} \mathrm{HPO}_{4}$ (1.98); $\mathrm{MgSO}_{4}(0.2) ; \mathrm{NaCl}(0.2) ; \mathrm{CaCl}_{2}$ (0.02) (Ramachandra et al., 1987). After $48 \mathrm{~h}$ of activation, cells were used to inoculate the medium to be fermented.

\section{Xylanase production in submerged fermentation}

Fermentation assays were carried out in duplicates, in $250 \mathrm{~mL}$ erlenmeyer flasks containing a medium composed by (g/L) $\mathrm{NaHPO}_{4}(5.3) ; \mathrm{K}_{2} \mathrm{HPO}_{4}(1.98)$; $\mathrm{MgSO}_{4}$ (0.2); $\mathrm{NaCl}(0.2) ; \mathrm{CaCl}_{2}$ (0.02); ground Napier grass $(1 \% \mathrm{w} / \mathrm{v})$, which was added as the lignocellulosic source (200 mesh). The medium was then sterilized for $15 \mathrm{~min}$ at $121^{\circ} \mathrm{C}$. Flasks were inoculated with activated cells $12 \% \mathrm{v} / \mathrm{v}$, and were kept under stirring at $120 \mathrm{rpm}$. Fermentation assays were carried out in conditions previously studied: $\mathrm{pH}$ 8.5-9.0.; temperature $37{ }^{\circ} \mathrm{C}$; stirring at 120 rpm (Adhi, 1989).

\section{Influence of nitrogen source}

The influence of the nitrogen source (urea $0.8 \mathrm{~g} / \mathrm{L}$; soybean bran at $1 \%$ and yeast at $0.6 \%$ ) was tested searching for higher activities of xylanase. The optimal levels of the inclusion of soybean bran as a source of nitrogen, between $0.5 \%$ and $1.5 \%$, were studied. The same conditions were employed.

\section{Influence of supplementation with vitamin-b complex}

The effects of supplementation with vitamin-B complex: cianocobalamine $25 \mu \mathrm{g} / \mathrm{mL}$; thiamine $0.005 \mathrm{~g} / \mathrm{mL}$; pyridoxine (B6) $0.0005 \mathrm{~g} / \mathrm{mL}$ ) added at $0.05 \%$ and $0.1 \%$ were compared to the control (no vitamins added).

\section{Supplementation and hydroxyethyl cellulose}

Supplementation of hydroxycethyl cellulose, based on kulkarni's study (kulkarni et al., 1999) was assessed together with supplementation with soybean bran and vitamin-b complex. in this case a factorial experimental design $3^{3-1}$ was employed (table 1). statistical dates was analysed by software statistica ${ }^{\circledR}$ version 5.0.

\section{Xylanase production in SSF}

The first experiments were conducted in erlenmeyer flasks using sugarcane bagasse $(70 \%)$, Napier grass $(20 \%)$, and soybean bran $(10 \%)$ as substrate. A salt solution $\left(\mathrm{Na}_{2} \mathrm{HPO}_{4}\right.$ and $\mathrm{K}_{2} \mathrm{HPO}_{4}$, 5.3 and $1.98 \mathrm{~g} / \mathrm{L}$, respectively) was used. The $\mathrm{pH}$ was adjusted to 8.6 with a $10 \% \mathrm{NaOH}$ solution. The flasks were covered with cotton and then sterilized for $15 \mathrm{~min}$ at $121^{\circ} \mathrm{C}$. Substrate was inoculated with $10 \mathrm{~mL}$ of cell suspension previously activated in shaker per gram of substrate.

\section{Definition of substrate composition}

Three components were used for studying the best substrate composition sugarcane bagasse, Napier grass, and soybean bran. The proportions of each component varied according to Table 2.

\section{Effect of moisture and inoculum rate}

The study of the effect of initial moisture and inoculation rate on the production of xylanase was carried out in $250 \mathrm{~mL}$ erlenmeyer flasks with the support of a $2^{3}$ central-point experimental design (moisture \%: 80, 90 and 95; inoculation rate: $10^{7}$, $10^{8}$, and $10^{9}$ ). The same described conditions were used in these experiments.

\section{Xylanase production in column bioreactors}

Columns were loaded with the solid substrate composed by: $70 \%$ sugarcane bagasse; $20 \%$ Napier grass and $10 \%$ soybean meal, humidified with a salt solution $\left(\mathrm{Na}_{2} \mathrm{HPO}_{4}\right.$ and $\mathrm{K}_{2} \mathrm{HPO}_{4}, 5.3$ and $1.98 \mathrm{~g} / \mathrm{L}$, respectively). This substrate was sterilized at $120^{\circ} \mathrm{C}, \mathrm{pH}$ was adjusted to 8.7 , and then columns were closed with cotton. Columns were inoculated with $10^{7}$ spores/g of substrate. Biomass was estimated by respirometric analysis. The saturated exhaust air from the class column bioreactor was passed through a silica gel column and analyzed by gas chromatography (Shimadzu GC-8A) to determine $\mathrm{O}_{2}$ and $\mathrm{CO}_{2}$ profiles at the gas outlet and relate them to biomass synthesis. 
Oxygen uptake rate (OUR) and volumetric flow of $\mathrm{CO}_{2}\left(\mathrm{~L} \cdot \mathrm{h}^{-1}\right)$ were estimated by a mass balance. From results on the production of OUR and $\mathrm{CO}_{2}$, some bioprocess parameters can be estimated. Estimation of biomass at a certain time $\left(\mathrm{X}_{\mathrm{n}}\right)$ is calculated assuming values for its yield based on oxygen consumption $\left(\mathrm{Y}_{\mathrm{X} / \mathrm{O}}\right)$ and biomass maintenance coefficient $\left(\mathrm{m}_{\mathrm{X}}\right)$. The software FERSOL was used in the calculations (RodriguezLeón et al., 1988).

\section{Xylanase production in tray type bioreactor and horizontal drum}

Solid-state fermentation (SSF) in trays was carried out using initial moisture adjusted to $95 \%$ with the nutritive solution. Substrate was inoculated with the spore suspension containing $10^{7}$ spores/g of dry substrate. The pre-inoculated substrate was distributed in trays $\left(0.0045 \mathrm{~m}^{3}\right)$ in order to obtain 2,4 , and $6 \mathrm{~cm}$ of bed thickness $(0.15,0.30$, and $0.45 \mathrm{~kg}$ of dry substrate, respectively). The trays were placed in a room with controlled temperature $\left(37^{\circ} \mathrm{C}\right)$ and humidity of about $95 \%$. Fermentation was carried out for $168 \mathrm{~h}$.

SSF was also conducted in horizontal drum (HD) bioreactor with $2 \mathrm{~kg}$ of dry substrate and $90 \%$ of initial moisture adjusted with the nutritive solution. In this case, initial moisture of substrate was lower than in tray-type bioreactor to avoid the excessive huddle of the substrate particles, which was observed in the first fermentations carried out in HD bioreactor. The inoculated substrate $\left(10^{7}\right.$ spores/g of dry CB) was placed inside the drum. As shown in Figure 1, the drum $\left(0.024 \mathrm{~m}^{3}\right)$ consisted of a shovel coupled to a motor axis that rotates at controlled speed. Thus, material was revolved 3 to 4 times a day avoiding the formation of preferential ways. Saturated air was inserted continually into drum in order to control substrate temperature and moisture (Prado et al., 2004). The airflow was maintained at $5 \mathrm{~L} / \mathrm{min}$. Fermentation was carried out for $168 \mathrm{~h}$ at room temperature.

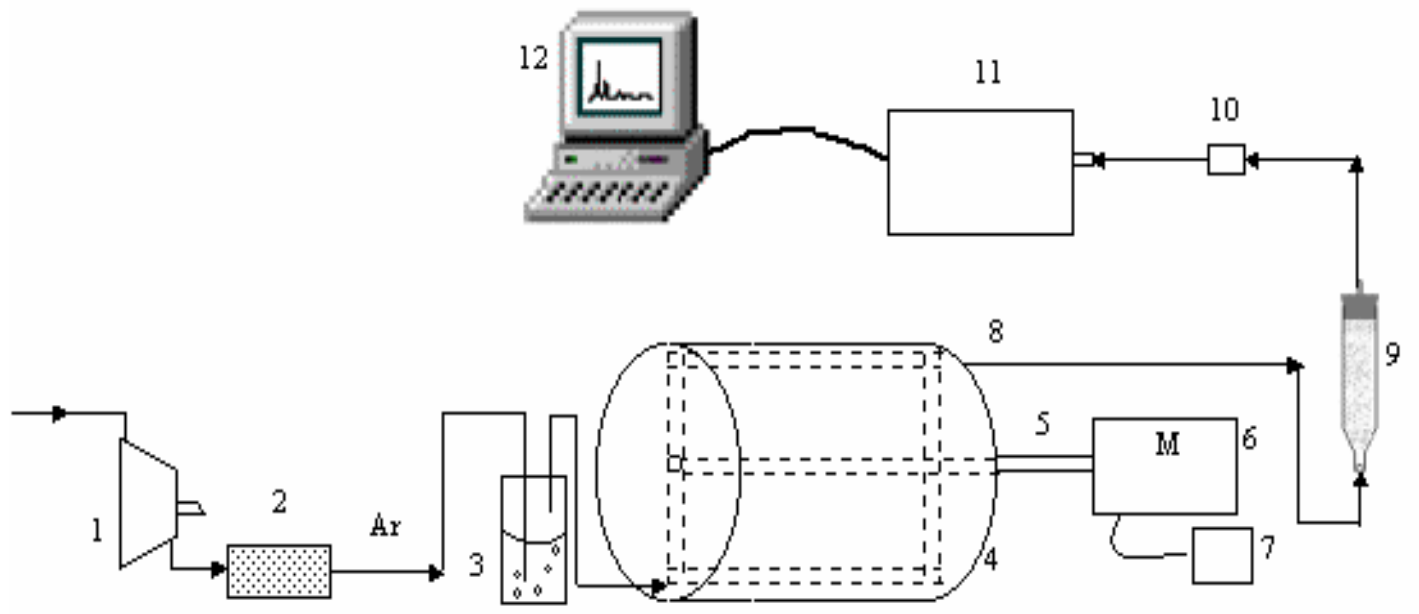

Figure 1 - Outline of the horizontal drum bioreactor and auxiliary equipments: (1) compressor, (2) air filter, (3) humidifier, (4) horizontal drum bioreactor, (5) axis, (6) motor, (7) speed controller, (8) air discharge, (9) silica gel column, (10) automatic injector, (11) gaseous chromatograph, (12) computer. 


\section{Enzyme assays}

Xylanase activity was assayed using $1 \%$ birchwood xylan (Sigma, USA) in $0.05 \mathrm{M}$ citrate buffer $(\mathrm{pH}=5.3)$, according to the method of Bailey et al. (1992). The release of reducing sugars was determined using the 3,5-

dinitrosalicylic acid (DNS) method (Miller, 1956) with a xylose standard curve. One unit (IU) of enzyme activity was defined as the amount of enzyme required to liberate $1 \mathrm{~mol}$ of reducing sugars per minute. The results of these analyses were expressed as units per gram of dry matter (IU/g).

\section{RESULTS AND DISCUSSION}

\section{Xylanase production in $\mathrm{SmF}$}

Results obtained with supplementation with soybean bran and vitamins, in association with hydroxyethyl cellulose, are discussed below. The first assays of xylanase production by $S$. viridosporus $\mathrm{T7A}$ in $\mathrm{SmF}$ using Napier grass as source of carbon showed a production of 4.1 $\mathrm{U} / \mathrm{mL}$. The study of the effect of the type of nitrogen source was also performed. In this case, soybean bran at $1 \%$ showed better results (5.0 $\mathrm{U} / \mathrm{mL}$ ) against $2.3 \mathrm{U} / \mathrm{mL}$ and $1.06 \mathrm{U} / \mathrm{mL}$ of yeast extract and urea, respectively. Soybean bran was then chosen as nitrogen source.

A $3^{3-1}$ factorial experimental design was carried out in order to optimize supplementation with soybean bran, B complex vitamins, and hydroxyethylcellulose (HEC). Results of this optimization are shown in Table 1.

The analysis of the results in Table 1 show that there was a positive response in xylanase yield when the greatest percentages of soybean bran, complex B vitamins and HEC were added to the medium (24.31 $\mathrm{U} / \mathrm{mL}$ ). Results obtained in this trial were much greater than those reported by Adhi (1989) in submerged culture $(0.3 \mathrm{U} / \mathrm{mL})$ using $S$. viridosporus strain T7A; those reported by Techapun (2001) (12 $\mathrm{U} / \mathrm{mL}$ ) using Streptomyces albus, and Antopoulos (2001) (15 U/mL) using Streptomyces sp. strain AB. However, they were similar to the yields reported by Mahesawari (2000) and Nascimento (2002), respectively equal to 22.0 and $28.4 \mathrm{U} / \mathrm{mL}$, using Streptomyces sp. Magnuson et al. (1999) reported a production of $8 \mathrm{U} / \mathrm{mL}$ by $S$. viridosporus T7A.

Table $1-3^{3-1}$ factorial experimental design for the supplementation with soybean bran, B complex vitamins, and HEC in order to optimize Streptomyces. viridosporus T7A xylanase yield in submerged fermentation.

\begin{tabular}{ccccc}
\hline Assay & Soybean bran \% & B complex vitamins \% & HEC \% & Activity U/mL \\
\hline 1 & 0.5 & 0.1 & 0.10 & 19.48 \\
2 & 0.5 & 0.2 & 0.20 & 22.49 \\
3 & 0.5 & 0.3 & 0.15 & 23.69 \\
4 & 1.0 & 0.1 & 0.20 & 23.14 \\
5 & 1.0 & 0.2 & 0.15 & 24.09 \\
6 & 1.0 & 0.3 & 0.10 & 21.00 \\
7 & 1.5 & 0.1 & 0.15 & 22.12 \\
8 & 1.5 & 0.2 & 0.10 & 23.62 \\
9 & 1.5 & 0.3 & 0.20 & 24.31 \\
\hline
\end{tabular}

There were no statistical differences $(\mathrm{p}<0.05)$ in the concentrations of soybean meal $(0.5 ; 1.0$, and $1.5 \%)$; B complex vitamins $(0.1 ; 0.2$ and $0.3 \%)$ and HEC $(0.1 ; 0.15$ and $0.2 \%)$ analyzed in this study. Results of the statistical analysis suggest that the lowest levels used of soybean meal $(0.5 \%)$, B complex vitamins $(0.1 \%)$ and HEC $(0.1 \%)$ led to good xylanase yield (data not shown). Cost-benefit ratio of this supplementation should be taken into account in order to determine the concentration of these elements to be added to the fermentation medium.

The presence of B complex vitamins is important for the growth and metabolism of microorganisms. It is believed that metabolic stimulus may increase xylanase production. The presence of HEC $0.1 \%$ led 
to greater enzyme activity, corroborating the results by Kulkarni et al. (1999), who showed that xylanase yield by Streptomyces sp may be induced by cellulose. Thus, this supplementation is probably beneficial for xylanase production, although the mechanism by which HEC increases production is not clear. Based on the results, a better xylanolytic activity could be obtained when the fermentation medium was supplemented with B complex vitamins and HEC.

\section{Xylanase production in SSF}

Xylanase production was carried in SSF with the purpose of comparing the production of this enzyme using different fermentation techniques. The same substrates employed in $\mathrm{SmF}$ were used in SSF. Sugarcane bagasse was used as support (higher proportion of fibers), Napier grass and soybean bran as sources of carbon and nitrogen, respectively. The studied proportions of the components are presented on Table 2. After 5 days of fermentation, it was verified that the composition that resulted in better xylanase production (390.4 $\mathrm{U} / \mathrm{mL}$ ) was that containing $70 \%$ of sugarcane bagasse, $20 \%$ of Napier grass, and $10 \%$ of soybean bran. It is believed that sugarcane bagasse is important for its high water retention capacity (Soccol and Vandenberghe, 2003), since the $S$. viridosporus is a microorganism which develops in elevated moisture (over 90\%). As the percentage of bagasse was increased, over $70 \%$, a decrease of the enzyme production was verified. Napier grass; contains less crude fiber contents than sugarcane bagasse, $28.2 \%$ and $41 \%$, respectively (data not shown). Consequently, the higher percentages of lignine, the lower is the amount of other nutrients (amino acids and vitamins), which may play an important part on the metabolism of the microorganism.

Table 2 - Optimization of the proportions of sugarcane bagasse, soybean bran and Napier grass for the production of xylanase by Streptomyces viridosporus T7A in SSF.

\begin{tabular}{ccccccccccc}
\hline \multicolumn{10}{c}{ Assays } \\
\hline Substrate (\%) & $\mathbf{1}$ & $\mathbf{2}$ & $\mathbf{3}$ & $\mathbf{4}$ & $\mathbf{5}$ & $\mathbf{6}$ & $\mathbf{7}$ & $\mathbf{8}$ & $\mathbf{9}$ & $\mathbf{1 0}$ \\
\hline Sugarcane bagasse & 10 & 20 & 30 & 40 & 50 & 60 & 70 & 80 & 90 & 100 \\
Napier grass & 80 & 70 & 60 & 50 & 40 & 30 & 20 & 10 & 0 & 0 \\
Soybean bran & 10 & 10 & 10 & 10 & 10 & 10 & 10 & 10 & 10 & 0 \\
Activity U/g & 21.2 & 25.5 & 32.9 & 60.4 & 150.4 & 210.1 & $390.4^{*}$ & 360.6 & 290.9 & 35.0 \\
\hline
\end{tabular}

\section{Study of the influence of moisture and} inoculation rate

Results of the study on the influence of the moisture content and inoculation rate on the xylanase production are shown in Table 3. In this study, moisture was noticed as a very significant physical parameter in the xylanase production process by SSF according to ANOVA the regression coefficient was determined 0,964. The studied variables were significant at $\mathrm{p}<0.05$. Therefore, higher percentages of moisture content provided higher levels of xylanase activity $(423.9 \mathrm{U} / \mathrm{g})$. By keeping the inoculation rate constant $\left(10^{7}\right.$ spores/g) the xylanasic activity changed from $229.0 \mathrm{U} / \mathrm{g}(80 \%$ of moisture) to $423.9 \mathrm{U} / \mathrm{g}(95 \%$ of moisture). The surface response graphic (data not shown) the ideal moisture is around $92 \%$.
This is a great matter in SSF since few materials used are able to retain so much moisture without letting water free. But, sugarcane bagasse, skinless, grinded, and sieved is one of the few agro-industrial residues which are capable of retaining higher volume of water per unit of dry weight (Soccol and Vandenberghe, 2003).

\section{Xylanase production and biomass estimation in SSF in column bioreactors}

One of the most important aspects of SSF, both in laboratory and pilot / industrial scales is biomass estimation. Methods commonly used in liquid culture are not adequate for SSF, due to the adhesion of the cells to the support/substrate, which affects this estimation. A way to evaluate growth and its relation with the production of biomolecules in SSF systems would be the analysis of $\mathrm{CO}_{2}$ production 
and $\mathrm{O}_{2}$ consumption during the process. $\mathrm{O}_{2}$ consumption and $\mathrm{CO}_{2}$ production are results of microbial metabolic activity; that is how microorganisms obtain energy for their growth and survival. Therefore, they may be used in the estimation of biomass synthesis. Many authors used respirometry in order to continuously assess $\mathrm{CO}_{2}$ and $\mathrm{O}_{2}$ that are released from bioreactors (Soccol and Vandenberghe, 2003).

Aeration in bioreactors is provided by the injection of compressed air. Then, gas exchanges take place between the air and the solid matrix. In SSF, aeration has the following aims: maintenance of aerobic conditions, withdrawal of $\mathrm{CO}_{2}$, control of temperature and humidity.
The evolution of $\mathrm{CO}_{2}$ and xylanase production was analysed. It may be observed that $\mathrm{CO}_{2}$ started to be detected after $12 \mathrm{~h}$ of fermentation, reaching a maximum flow $(0.50 \mathrm{mM} / \mathrm{h})$ in $21 \mathrm{~h}$. From this moment on, there was a decrease in the amount of $\mathrm{CO}_{2}$ released until $41 \mathrm{~h}$. Then, it remained constant $(0.20 \mathrm{mM} / \mathrm{h})$ until the end of the fermentation process, showing that the microorganism continued breathing (data not shown). Xylanase production began only after $24 \mathrm{~h}$ of fermentation $(4.65 \mathrm{U} / \mathrm{g})$, reaching a maximum $(76.2 \mathrm{U} / \mathrm{g})$ in $96 \mathrm{~h}$. This fact demonstrated that production was not associated with $S$. viridosporus growth and the aeration had a negative effect over xylanase accumulation.

Table 3 - Effect of humidity and inoculum rate o xylanase production by Streptomyces viridosporus T7A in solid state fermentation.

\begin{tabular}{ccc}
\hline Moisture \% & Inoculation & Activity U/g \\
\hline 90 & $10^{9}$ & 346.1 \\
95 & $10^{8}$ & 350.0 \\
80 & $10^{7}$ & 229.0 \\
80 & $10^{8}$ & 193.5 \\
95 & $10^{9}$ & 200.0 \\
90 & $10^{7}$ & 333.9 \\
95 & $10^{7}$ & 423.9 \\
90 & $10^{8}$ & 90.8 \\
80 & $10^{9}$ & 319.3 \\
\hline
\end{tabular}

Production of the enzyme in this trial, although not carried out in the conditions previously established as favorable, was not satisfactory due to several factors. First of all, substrate moisture was not ideal (90\%) because free water was released from the material. It was extremely difficult to maintain temperature at $37^{\circ} \mathrm{C}$, what contributed for a lower xylanase production. Even then, the behavior and growth of the microorganism as well as the relationship between growth and xylanase production could be predicted from the results obtained. A decrease in xylanase production could be observed after $97 \mathrm{~h}$ of fermentation. This decrease may be due to the presence of inhibiting substances in the medium, such as proteases that were being produced concomitantly. Other inhibitors may have a role in this occurrence, such as sugars that were released during the process, as well as other substances. Further studies should be conducted in order to better understand this finding.

Biotechnological parameters of the process were estimated from values calculated for $\mathrm{CO}_{2}$ production. Mass balance for $\mathrm{CO}_{2}$ production was considered to be parallel with $\mathrm{O}_{2}$ consumption, for there were problems in the analytic system for $\mathrm{O}_{2}$. The equation by Sato et al. (1983) was used in the calculations.

Biomass calculation procedure $(\mathrm{Xn})$ in a given period of time ( $\mathrm{t}$ ) consists in the estimation of biomass yield based on $\mathrm{O}_{2}$ consumption and the maintenance coefficient (m). FERSOL software (Rodriguez-Léon et al., 1988) was used in the calculations. Two biomass points were measured analytically for the samples, at 0 and $26 \mathrm{~h}$. Values measured were compared with predicted ones. The software determined the coefficients for the equation by means of successive approaches. Biomass yield ( $\mathrm{Y} \times / 0$ ) was determined using the values obtained in 
the trial, based on $\mathrm{O}_{2}$ consumption equal to 2,816 g per biomass unit and a maintenance coefficient equal to $0,0036 \mathrm{~g}$ of $\mathrm{O}_{2}$ consumed of biomass ${ }^{-1} \mathrm{~h}^{-1}$.

Biomass estimated from 0 to $26 \mathrm{~h}$ of fermentation, during exponential growth phase, ranged from 0.1 to $0.44 \mathrm{~g}$. Based on this biomass estimation, specific growth speed $(\mu)$ was equal to $0.126 \mathrm{~h}^{-1}$, and regression coefficient $\left(\mathrm{R}^{2}\right)$ equal to 0.987 .

Xylanase production in tray type bioreactor and horizontal drum

Table 4 presents the results of xylanase production by $S$. viridosporus T7A in tray-type bioreactor (aeration by diffusion) and horizontal drum (forced aeration). Xylanase activity decreased significantly with the increase of scale independently of aeration method: $90 \mathrm{U} / \mathrm{g}$ dry substrate and 80.5 U/g dry substrate in tray-type and horizontal drum bioreactor, respectively, after seven days. In traytype bioreactor some operational problems such as lost of humidity due to the high temperature of the process $\left(37^{\circ} \mathrm{C}\right)$ were verified. In horizontal drum it was possible to observe a decrease of xylanase activity, probably due to the medium heterogeneity and agglomeration, which creates serious limitations of air and nutrients diffusion. New experiments are certainly needed to optimize these processes.

Table 4 - Comparison of xylanase production in different types of bioreactors by solid-state fermentation

\begin{tabular}{ccc}
\hline Tray-Type Layer $(\mathrm{cm})$ & $(\mathbf{U} / \mathbf{g})$ & Horizontal $\operatorname{drum}(\mathbf{U} / \mathbf{g})$ \\
\hline 2 & 62.26 & \\
4 & 90.00 & 80.50 \\
6 & 85,63 & \\
\hline
\end{tabular}

\section{CONCLUSIONS}

It can be stated, in light of the results obtained in this study, that the production of xylanase of Streptomyces viridosporus T7A was satisfactory when compared to the results obtained by other researchers with the same strain. The fermentative process proposed in this study is viable as it allows the use of low-cost agroindustrial sub-products and residues. The best results were obtained with supplementation using soybean bran at $1 \%(\mathrm{w} / \mathrm{v})$. There was an increase on xylanase production $(24.31 \mathrm{U} / \mathrm{mL})$ in $\mathrm{SmF}$ when the vitamin-B complex and HEC were added to the medium. With respect to solid-state fermentation, the study to determine the substrate-support revealed that the proportion in which best results were obtained for xylanase production was: $70 \%$ of sugarcane bagasse, $20 \%$ of Napier grass, and $10 \%$ soybean bran; the inoculation may be directly conducted with spores. Maximal activity of xylanase was reached $(423.7 \mathrm{U} / \mathrm{g})$ with and inoculation rate of $10^{7}$ spores/g and initial humidity of $95 \%$. With respect to the physical factors studied, moisture played an important influence on xylanase production as high percentages resulted in better productions. Sugarcane bagasse is a proper substrate-support since it showed high water retention capacity. Aeration, at the tested levels, had no significant effect over xylanase production. By respirometric analysis it was possible to verify that xylanase production was not associated with $S$. viridosporus growth. This fact shows that the process of xylanase production presents great perspectives if the technique of SSF is conducted without forced aeration. In this way, the process must be conducted in SSF bioreactors that do not use forced aeration such as tray-type bioreactors. Some studies of xylanase purification will also be performed.

\section{ACKOWLEDGEMENTS}

The financial resources for the conduction of this study were supported by the project BioAgroPar financed by FINEP, SETI/PR, and Fundação Araucária/PR; and by $\mathrm{CNPq} /$ Brazil.

\section{RESUMO}

A produção de xilanase por Streptomyces viridosporus T7A foi realizada em fermentação submersa (FSm) e fermentação no estado sólido 
(FES) utilizando resíduos e sub-produtos agroindustriais. Capim Napier, bagaço de cana e farelo de soja foram empregados como fonte de carbono, suporte/substrato e fonte nitrogênio, respectivamente. Em FSm, o capim Napier (1\% $\mathrm{p} / \mathrm{v})$ foi suplementado com farelo de soja $(1,5 \%$ $\mathrm{p} / \mathrm{v})$, hidroxietilcelulose $(0,15 \%)$ e vitaminas do complexo B $(1,5 \%)$ sendo que a produção de xilanase atingiu $23.41 \mathrm{U} / \mathrm{mL}$. Em FES, o efeito dos seguintes parâmetros foi estudado: composição do substrato (bagaço de cana, Capim Napier e farelo de soja), umidade inicial, aeração e taxa de inoculação. A mais elevada produção de xilanase $(423,9 \mathrm{U} / \mathrm{g})$ foi atingida com $70 \%$ bagaço de cana, $20 \%$ de capim Napier e $10 \%$ farelo de soja, $90 \%$ de umidade inicial e $10^{7}$ células/g substrato.

\section{REFERENCES}

Adhi, T. P., Korus, R. A., Crawford, D. L., (1989), Production of major extracellular enzymes during lignocellulose degradation by two Streptomycetes in agitated submerged culture. Appl. Environ. Microbiol., 1165-1168.

Alberton, L. R., Vandenberghe, L. P. S., Assman, R., München, L., Ciffoni, E. M. G., Pachaly, J. R., Soccol, C. R. (2006), Efeito do extrato bruto enzimático de Streptomyces viridosporus T7A sobre a digestibilidade de matéria seca in vitro para ruminantes. Arq. Ciên. Vet. Zool. Unipar, 9 (1), 29-36.

Antonopoulos, V. T.; Hernandez, M., Arias, M. E., Mavrakos, E., Ball, A. S. (2001), The use of extracellular enzyme from Streptomyces albusi ATCC 3005 for the bleaching of eucalyptus kraft pulp. Appl. Microbiol. Biotechnol., 54, 92-97.

Bailey, M. J., Biely, P., Poutanen, K. (1992), Interlaboratory testing of methods for assay of xylanase activity. J. Biotechnol., 23, 257-271.

Georis, J., Giannotta, F., De Buyl, E.,Granier, B., Frère, J-M. (2000), Purification and properties of three endo- $\beta-1,4$-xylanases produced by Streptomyces sp. Strain S38 which differ in their ability to enhance the bleaching of kraft pulps. Enzyme Microb. Technol., 26,178-186.

Goyal, M., Kalra, K. L., Sareen, V. K., Soni, G. (2008), Xylanase production with xylan rich lignocelulósico wastes by a local soil isolate of Trichoderma viridae. Braz. J. Microb., 39, 535541.
Kulkarni, N., Shendye, A., RAO, M. (1999), Molecular and biotechnology aspects of xylanases. FEMS Microb. Ver., 23, 411-456.

Kronbauer, E. A. W., Peralta, R. M., Osaku, C. A., Kadowaki, M. K. (2007), Produção de xilanase de Aspergillus caslei em diferentes fontes de carbono, $B$. CEPPA., 25 (2), 207-216.

L.I. (1995), Biotransformation of Solid Waste from Cassava Starch Production by Rhizopus in Solid State Fermentation. Part I - Optimization of the Culture Conditions and Growth Kinetics. Braz. Arch. Biol. Technol, 38, 1311-1318

Lonsane, B. K., Ghidyal, N. P., Budiatman, S., Ramakrishna, S. V. (1985), Engineering aspects of solid state fermentation. Enzyme Microb. Technol., 7, 258265.

Machado, C. M. (2000), Produção de Ácido Giberélico por Fermentação no Estado Sólido em Bio-Resíduos da Agroindústria do Café, Mastre Science Thesis,Universidade Federal do Paraná, Curitiba, Brazil.

Maesawari, M. U., Chandra, T. S. (2000), Production and potential applications of xylanase from a new stratin of Streptomyces viridosporus. World J. Microbiol. Biotechnol., 16, 257-263.

Magnuson, T. S, Crawford, D. L. (1997), Purification and characterization of an alkaline xylanase from Streptomyces viridosporus T7A. Enzyme Microbiol. Technol., 21 (3), 160- 164.

Miller, L. (1959), Use of dinitrosalicylic acid reagent for determination of reducing sugar. Anal. Chem., 31, 426428.

Moo-Young, M., Moreira, A. R., Tengerdy, R. P. (1983), Principales of solid-substrate fermentation. In-The Filamentous Fungi. London, 4, pp. 177-144.

Muth, G., Brolle, D. F., Wohlleben, W. (1998), Genetics of Streptomyces In-Manual of Industrial Microbiology and Biotechnology, A. DEMAIN L., J. DAVIES. ASM Press, Washington, 2, 353.

Pandey, A., Soccol, C. R., Rodrigez-Léon, J. A., Nigam, P. (2001), In-Solid-State Fermentation in Biotechnology: Fundamentals and Applications, New Delhi, Asiatech Publishers, Inc, $221 \mathrm{p}$.

Prado, F. C., Vandenberghe, L. P. S., Lisboa, C., Paca, J., Pandey, A., Soccol, C. R. (2004), Eng. Life Sci, 4 (2).

Prado, F. C.; Vandenberghe, L. P. S.; Soccol, C. R. (2005), Relation between Citric Acid Production by Solid State Fermentation from Cassava Bagasse and Respiration of Aspergillus niger LPB 21 in Semipilot Scale. Braz. Arch. Biol. Technol., 48, 29- 36

Raimbault, M., Alazard, D. (1980), Culture method to study fungal growth in solid fermentation. European $J$. Appl. Microbiol. Biotechnol., 9, 199-209. 
Ramachandra, M., Crawford, D. L., Pometto, A. L. (1987), Extracellular enzyme activities during lignocellulose degradation by Streptomyces spp. A comparative study of wild type and genetically manipulated strains. Appl. Environ. Microbiol., 2754-2760.

Rawadeshdeh, R., Saadoun, I., Mahasneh, A. (2005), Effect of cultural conditions on xilanase production by Streptomyces sp. (strain lb 24D) and its potential to utilize tomato pomace. African J. Biotechnol., 4 (3), 251-255.

Rodriguez-León, J. A., Sastre, L., Echevarria, J., Delgado, G., Bechstedt, W. A (1988), Mathematical approach for the estimation of biomass production rate in solid-state fermentation. Acta Biotechnol., 8, 307-310.

Sato, K., Nagatani, M., Nakamuri, K. I., Sato, S. (1983), Growth estimation of Candida lipolytica from oxygen uptake rate in a solid culture with forced aeration. J. Ferment. Technol., 61, 623-629.
Soccol, C. R.; Stertz, S.C.; Raimbault,M.; Pinheiro, L.I. (1995), Biotransformation of Solid Waste From Cassava Starch Production by Rhizopus in Solid State Fermentation. Part I - Optimization of the Culture Conditions and Growth Kinetics. Braz. Arch. Biol. Technol, 38, 1311-1318

Soccol, C. R. and Vandenberghe, L. P. S. (2003), Overview of applied solid-state fermentation in Brazil. Biochem. Eng. J, 13, 205-218.

Techapun, C. Sinsuwongwat, S. Poosaran, N., Watanabe, M., Sasaki, K. (2001), Production of a cellulase-free xylanase from agricultural waste materials by a thermotolerant Streptomyces sp. Biotechnol. Lett., 23 , 1685-1689. 